DOI: 10.12731/2658-6649-2019-11-5-145-149

УДК 616-097

\title{
КОМПЛЕКСНОЕ ПРИМЕНЕНИЕ МЕТОДОВ ИФА И ПЦР ДЛЯ ДИАГНОСТИКИ ЭПШТЕЙН-БАРР ВИРУСНОЙ ИНФЕКЦИИ
}

\author{
Смирнова С.С., Иванова Н.А., Степанова Т.Ф.
}

В статье рассматриваются результаты обследования пациентов ФБУН ТНИИКИП Роспотребнадзора на Эпштейн-Барр-вирусную инфекцию. Подтвердилось, что сочетание методов ИФА и ПЦР дает более полную информацию для постановки клинического диагноза, чем при изолированном их применении.

Ключевые слова: иммуноферментный анализ (ИФА); полимеразная иепная реакиия (ПЦР); вирус Эпштейна-Барр (ВЭБ); Эпштейн-Барр-вирусная инфекция (ВЭБИ).

\section{COMPLEX APPLICATION OF ELISA AND PCR METHODS FOR DIAGNOSTICS EPSTERINE-BARR VIRAL INFECTION}

\section{Smirnova S.S., Ivanova N.A., Stepanova T.F.}

The article discusses the results of the examination of patients with FBUN TNIIKIP of Rospotrebnadzor for Epstein-Barr-virus infection. It was confirmed that a combination of ELISA and PCR methods provides more complete information for making a clinical diagnosis than when isolated using them.

Keywords: enzyme-linked immunosorbent assay (ELISA); polymerase chain reaction (PCR); Epstein-Barr virus (EBV); Epstein-Barr virus infection (EBI).

\section{Введение}

Одной из актуальных проблем современной медицины является высокая заболеваемость герпесвирусными инфекциями.

Одной из самых распространенных скрытых инфекций является, вызванная вирусом герпеса человека 4 типа или вирусом Эпштейна-Барр (ВЭБ) - Эпштейн-Барр-вирусная инфекция (ВЭБИ). Чаще всего зараже- 
ние ВЭБ происходит в раннем детском или юношеском возрасте и существует в виде скрытой инфекции в течение всей жизни зараженного человека. Широкая распространенность ВЭБИ, а также ее роль в формировании патологии иммунной системы, была установлена, благодаря достижениям лабораторной медицины при применении различных методов диагностики: молекулярно-генетических, иммунологических и вирусологических.

ВЭБ представляет собой В-лимфотропный вирус герпеса человека, относящийся к семейству Herpesviride и обладает способностью пожизненно персистировать в организме человека [1]. ВЭБ способен поражать два типа клеток: эпителий верхних дыхательных путей и пищеварительного тракта, а также В-лимфоциты. Обладая различными методами иммуносупрессии и ускользания от иммунного ответа хозяина, ВЭБ может вызывать хроническое течение болезни. ВЭБ вызывает такие различные заболевания, как инфекционный мононуклеоз, злокачественная лимфома Беркитта, злокачественная носоглоточная карцинома.

По мере распространения инфекции, во всех клетках появляются уникальные антигены ВЭБ-ранний антиген (ЕA), антиген вирусного капсида (VCA), мембранный антиген (MA), ядерный антиген (EBNA). В ответ на их появление синтезируются специфические антитела, которые являются ценными маркерами заболевания. На комплексном выявлении антител к специфическим антигенам основан неспецифический тест на инфекционный мононуклеоз, позволяющий провести достоверную лабораторную диагностику инфекции и определить стадию и форму инфекционного процесса [2].

Цель нашей работы: сопоставление комплексного применения методов ИФА и ПЦР по сравнению с изолированным их применением для диагностики ВЭБИ среди пациентов ФБУН ТНИИКИП Роспотребнадзора за 2018 год.

\section{Материалы и методы}

В клинике ФБУН ТНИИКИП Роспотребнадзора за 2018 год проведены обследования 1198 пациентов на ВЭБ. У больных исследовали сыворотку крови методом ИФА на наличие наиболее специфических и чувствительных маркеров ВЭБИ - иммуноглобулинов класса M (VCA$\mathrm{IgM})$ и класса G (EA-IgG, NA-IgG) с использованием диагностических тест-систем ЗАО «Вектор-Бест» (Россия, Новосибирск). Помимо этого использовался метод ПЦР для выявления и количественного определения ДНК ВЭБ в клиническом материале у 160 пациентов. Исследование 
и оценка результатов производилось по стандартным методикам и в соответствии с инструкциями.

\section{Результаты исследования}

Среди всех пациентов, обследованных методом ИФА на антитела класca IgM к ВЭБ с положительным результатом зарегистрировано $19,9 \pm 1,2 \%$, на антитела EA-IgG - 11,2 $\pm 0,9 \%$, на антитела NA-IgG - 70,5 $\pm 1,3 \%$ наблюдений. Из всех серопозитивных пациентов по частоте встречаемости антител класса IgM преобладают дети, на их долю приходится 75,6 22,8\%, взрослого населения $-24,4 \pm 2,8 \%$, что объясняется большей восприимчивостью детей к вирусным инфекциям в силу недостаточности иммунной системы. Процент положительных результатов антител EA-IgG среди детей равен $66,4 \pm 4,1 \%$, взрослых - 33,6 4,1\%. Антитела NA-IgG распределены так: $53,4 \pm 1,7 \%$ инфицированных детей и $46,6 \pm 1,7 \%$ взрослых.

У 33 пациентов выявлено наличие только IgM VCA, что свидетельствует о первичном недавнем инфицировании. Выявление VCA-IgM в сочетании с EA-IgG говорит о недавно перенесенной инфекции с персистированием IgM VCA в крови (25 пациентов). Наличие высоких значений EA-IgG в сочетании с невысокими показателями NA-IgG и VCA-IgM указывает на реактивацию активной хронической инфекции либо на позднюю первичную инфекцию (44 пациента). Отсутствие VCA-IgM и наличие NAIgG, а также невысокие значения либо отсутствие EA-IgG свидетельствует хроническом течении инфекции, такие показатели зарегистрированы у 45 человек.

В целом среди всех обследованных методом ПЦР - 46,3 4 , $0 \%$ приходится на детей, среди которых $35,1 \pm 5,6 \%$ с положительным результатом, в то время как у взрослых зарегистрировано $16,3 \pm 4,0 \%$ с обнаруженными копиями вируса Эпштейна-Барр в исследуемом материале.

\section{Обсуждение}

Сочетание методов ИФА и ПЦР дает более четкую картину течения болезни. Так, из 160 пациентов, обследованных двумя методами, у одного отмечена очень ранняя первичная инфекция, так как антитела к ВЭБ не обнаружены, а методом ПЦР было выявлено $2,5^{*} 10^{5}$ копий ДНК вируса ВЭБ. Из 40 пациентов с выявленными копиями ДНК вируса в исследуемом материале у 5 отмечена первичная инфекция, так как отмечено наличие антител VCA-IgM и отсутствии антител NA-IgG. У 11 человек, имеющих антитела VCA-IgM и NA-IgG, наблюдается обострение хронической фор- 
мы течения болезни. И у 23 человек, имеющих серопозитивные результаты на NA-IgG и с отсутствующими антителами VCA-IgM, отмечена хроническая форма заболевания.

Среди 120 пациентов с отрицательным результатом на наличие ДНК вируса Эпштейна-Барр, у 111 пациентов, обследованных методом ИФА, обнаружены антитела NA-IgG, что говорит о ранее перенесенной инфекции. Таким образом, сочетание данных методов дает более четкую картину постановки клинического диагноза.

\section{Заключение}

Применение комплекса методов ПЦР и ИФА для диагностики ЭпштейнБарр-вирусной инфекции дает дополнительную информацию для постановки клинического диагноза, что подтверждают результаты настоящего исследования.

Информация о конфликте интересов. Авторы заявляют об отсутствии конфликта интересов.

Информация о спонсорстве. Исследование не имело спонсорской поддержки.

\section{Список литературы}

1. Савицкая В.В. Значение метода ИФА в диагностике ВЭБ / Материалы 18-й международной научной конференции: в 3 ч. Минск: Информационно-вычислительный центр Министерства финансов Республики Беларусь, 2018. C. $327-328$.

2. Малашенкова И.К. Клинические формы хронической Эпштейна-Барр вирусной инфекции - вопросы диагностики и лечения // Лечащий врач. 2003. № 9. С. 15-21.

\section{References}

1. Savitskaya V.V. Znachenie metoda IFA $v$ diagnostike VEB [The significance of the IFA method in diagnostics of VEB] / Proceedings of the 18th international scientific conference: at 3 pm Minsk: Information and Computing Center of the Ministry of Finance of the Republic of Belarus, 2018, pp. 327-328.

2. Malashenkova I.K. Klinicheskie formy hronicheskoj Epshtejna-Barr virusnoj infekcii - voprosy diagnostiki i lecheniya [Clinical forms of Epstein - Barr chronic viral infection - issues of diagnosis and treatment]. Treating doctor. 2003. № 9, pp. 15-21. 


\section{ДАННЫЕ ОБ АВТОРАХ \\ Смирнова Светлана Сергеевна, биолог \\ Иванова Наталья Александровна, биолог \\ Степанова Татьяна Федоровна, директор, доктор медицинских наук, профессор \\ Федеральное бюджетное учреждение науки «Тюменский науч- но-исследовательский институт краевой инфекционной патоло- гии» Роспотребнадзора \\ ул. Республики, 147, г. Тюмень, 625000, Российская Федерация info@tniikip.rospotrebnadzor.ru}

DATA ABOUT THE AUTHORS

Smirnova Svetlana Sergeevna, biologist

Ivanova Natalia Aleksandrovna, biologist

Stepanova Tatyana Fedorovna, Director, Doctor of Medical Sciences, Professor

Tyumen Research Institute of Regional Infectious Pathology, Rospotrebnadzor

147, Respubliki Str., Tyumen, 625000, Russian Federation

info@tniikip.rospotrebnadzor.ru 